\title{
Amerykański bunt przeciwko merytokracji. Recenzja Twilight of the Elites: America after Meritocracy Christophera Hayesa, Excellent Sheep: The Miseducation of the American Elite and the Way to a Meaningful Life Williama Deresiewicza i Listen, Liberal: Or, What Ever Happened to the Party of the People Thomasa Franka
}

Będzie to panowanie inteligencji naukowej, najbardziej arystokratyczny, despotyczny, arogancki i pogardliwy reżim ze wszystkich. Da to nową klasę, nową hierarchię rzeczywistych i rzekomych naukowców i uczonych, a świat zostanie podzielony na mniejszość, która będzie rządziła w imieniu wiedzy i na ogromną nieuświadomioną większość.

Michał Bakunin

Dnia 9 listopada 2016 roku liberalna prasa zachodniego świata, a także liberalny sektor sieci - stanowiący żywe odbicie opinii i uczuć globalnej klasy zamożnego i dobrze wykształconego mieszczaństwa - rozpoczęły debatę nad największą od wielu dekad porażką swojej ideologii, zwycięstwem Donalda Trumpa i przegraną Hillary Clinton w amerykańskich wyborach prezydenckich. Gdyby sądzić na podstawie przedwyborczych narracji, stała się rzecz pozbawiona sensu - kandydatka przez całe dorosłe życie skrupulatnie konstruująca CV przyszłej prezydentki, najbardziej kompetentna i doświadczona osoba, jaka kiedykolwiek ubiegała się o najwyższy urząd państwowy USA (Reuters 2016), przegrała z człowiekiem posługującym się językiem angielskim na poziomie trzecioklasisty (Shafer 2015), z wulgarnym, pozbawionym polotu i gustu kryptofaszystą, ksenofobicznym demagogiem, niezdolnym do otwarcia ust bez obrażenia jakiejkolwiek grupy wyborców (Frank 2016a). W kolejnych dniach, wraz ze stygnięciem emocji, pojawiły się pierwsze próby wyjaśnienia zagadki tego zwycięstwa - równie, jeśli nie bardziej, zaskakującego dla badaczy społecznych, co dla globalnej „klasy kreatywnej”. Miało ono leżeć w międzynarodowym marszu esencjonalistycznego nacjonalizmu, głęboko zakorzenionym rasizmie i mizoginii amerykańskiej prowincji, bezprecedensowej mobilizacji uprzywilejowanych, ale niechcących czy niepotrafiących zdać sobie sprawy z własnego uprzywilejowania. 
Celem tej recenzji jest próba przedstawienia nurtu myśli stanowiącej alternatywę dla przedstawionych powyżej wyjaśnień sukcesów populizmu w krajach takich jak Stany Zjednoczone czy Wielka Brytania. Nurt ten przywiązuje znaczną wagę zarówno do porażek, jak i niefortunnych sukcesów systemu edukacyjnego, a w szczególności systemu szkolnictwa wyższego. Recenzowane publikacje to Twilight of the Elites: America after Meritocracy Christophera Hayesa, Excellent Sheep: The Miseducation of the American Elite and the Way to a Meaningful Life Williama Deresiewicza i Listen, Liberal: Or, What Ever Happened to the Party of the People Thomasa Franka. W zamyśle autorów książki te mówią o sytuacji w Stanach Zjednoczonych, ale ze względu na istnienie globalnej sieci gospodarczych powiązań i - w coraz większym stopniu - globalnej struktury klasowej są one też relewantne dla Polski i Europy. Gdyby zgodzić się z analizami Franka, Deresiewicza i Hayesa, to sukcesy populistów należałoby uznać nie (czy nie wyłącznie) za rasistowski czy natywistyczny bunt przeciwko coraz bardziej zróżnicowanemu społeczeństwu, tylko za próbę obalenia skorumpowanego, niesprawiedliwego i niedemokratycznego systemu społecznego, w jaki wyrodziła się współczesna merytokracja.

\section{Władza najzdolniejszych}

Podobnie jak „społeczeństwo obywatelskie” (Starego 2016), merytokracja zdaje się ideą prawie pozbawioną wrogów. O ile w odniesieniu do demokracji z chęcią stosuje się Churchillowski cytat o „systemie rządów najgorszym z możliwych, poza wszystkimi innymi, których próbowano od czasu do czasu", o tyle merytokratyczne reguły gry do tego stopnia stały się częścią zdrowego rozsądku, że społeczeństwo odruchowo postrzega edukację przez ich pryzmat (Melosik 2015). Nie kojarzy się ona - pomimo znaczenia drugiego członu pojęcia - z systemem, za pomocą którego jedni władają drugimi, tylko ze sposobem konstruowania stosunków społecznych kierowanym elementarnymi zasadami sprawiedliwości. Zasady te mówią, że pozycja i rola każdego człowieka powinna być determinowana wyłącznie przez jego czy jej zdolności, ambicje i determinację. O ile dla centroprawicowych neoliberałów za takie „sprawiedliwe konstruowanie nierówności” (Stańczyk 2013) ma odpowiadać działanie wolnego rynku, o tyle centrolewica widzi analogiczną szansę w funkcjonowaniu systemu powszechnej edukacji. Można powiedzieć, że jak nie ma kapitalizmu bez rynków czy autokracji bez wojska, tak nie można wyobrazić sobie merytokracji bez systemu szkolnictwa wyższego.

To ogromne znaczenie jakie w merytokratycznych systemach społecznych jest przypisywane edukacji, w szczególności edukacji wyższej - i to najlepiej takiej, której instytucje są poszeregowane zgodnie z silną i przejrzystą hierarchią - blisko wiąże uniwersytety, najlepsze szkoły średnie i podstawowe z władzami tego świata. System społeczny, który powstaje w wyniku tego sojuszu, stał się w 2012 roku przedmiotem opisu Christophera Hayesa w książce Twilight of the Elites. Funkcjonowanie elitarnych szkół wyższych i ich rolę w formowaniu "etosu” nowych merytokratycznych elit opisał w roku 2014 William Deresiewicz w Excellent Sheep. 
Wreszcie opublikowana w przeddzień wyborów prezydenckich książka Listen, Liberal Thomasa Franka (znanego w Polsce z jednej ze swoich poprzednich publikacji Co z tym Kansas?: czyli powieść o tym, jak konserwatyści zdobyli serce Ameryki) zajmuje się politycznymi instytucjami wykształconej „klasy liberalnej”. Szczególną uwagę zwraca na sposób, w jaki przekształciła ona - wcześniej blisko powiązaną ze związkami zawodowymi - Partię Demokratyczną. Z perspektywy pedagogicznej najciekawszą z tych publikacji wydaje się być książka Deresiewicza - należy jednak zdać sobie sprawę, że wraz z rozwojem systemu merytokratycznego granice oddzielające instytucje edukacyjne od społeczeństwa zacierają się. Edukacja, związane z nią pojęcia, sposoby myślenia, hierarchie, wartości oraz pragnienia wydostają się poza mury szkół i strukturyzują życie jednostek i całego społeczeństwa. Jest to „inwazja” nie całkiem odmienna od tej dokonanej wcześniej przez akademicką ekonomię. By zrozumieć jej konsekwencje oraz sposób, w jaki w procesie sprzężenia zwrotnego zmienia ona same szkoły, ich funkcje oraz społeczne i polityczne wymagania wobec nich, trzeba patrzeć na cały system społeczny - od gospodarki po politykę. Stany Zjednoczone są dobrym punktem wyjścia dla takiej analizy, ponieważ kraj ten od blisko stu lat dyktuje globalne edukacyjne trendy. Również na drodze do merytokracji zaszedł on dalej i wcześniej niż inne społeczeństwa.

\section{Pół wieku tresury}

Pierwszą konsekwencją uzależnienia kształtu przyszłej hierarchii społecznej od osiągnięć szkolnych jest powszechny i rozpoczynający się w bardzo wczesnym wieku przymus samodoskonalenia.

Dla członków wyższej klasy średniej - najbardziej ambitnych, a jednocześnie niedysponujących kapitałem finansowym w stopniu pozwalającym na przełamanie „oporu" uniwersytetów przed przyjmowaniem mniej zdolnych kandydatów oznacza to projektowanie całego dzieciństwa zgodnie z rekrutacyjnymi wymogami elitarnych koledży.

Jak pisze socjolog Mitchell L. Stevens, „zamożne rodziny wytworzyły styl życia wokół procesu wytwarzania mierzalnych cnót u dzieci”. Przez „mierzalne” rozumie się tu: możliwe do zamieszczenia na podaniu o przyjęcie do koledżu (Deresiewicz $2014)^{1}$.

System rekrutacji oparty na testach SAT (stanowiących odpowiednik polskiej matury), a także możliwych do udokumentowania zajęciach pozaszkolnych, osiągnięciach sportowych i - szczególnie istotnych dla elitarnych uniwersytetów "zdolnościach przywódczych” ma gwarantować „wszechstronność” kandydatów. Bogactwo wachlarza działań mogących zwiększyć szanse na dostanie się do upragnionej szkoły w połączeniu z bezwzględną konkurencją skutkuje powstaniem ścieżek życiowych, w których nic nie jest dziełem przypadku, a każde działanie jest podporządkowywane możliwości osiągnięcia wyższego miejsca w społecznej hierarchii. Prowadzi to do specyficznej odmiany alienacji, w ramach której kryteria

1 Tłumaczenia - Ł.S., jeśli nie zaznaczono inaczej. 
rekrutacji, mające niegdyś głęboki (choć nie zawsze godny pochwały [zob. Karabel 2005]) sens społeczny, są całkowicie opróżniane z wartości wykraczającej poza ich funkcje waluty, pozwalającej wkupić się w łaski elitarnych szkół.

Dzieci robią to wszystko, ponieważ wiedzą, że powinny, a nie dlatego, że [którekolwiek z tych działań] ma sens dla nich czy kogokolwiek innego. Gdyby powiedzieć uczniom, że by dostać się do Harwardu, mają stanąć na głowach, to zrobiliby to tak samo gorliwie, tak samo sumiennie, tak samo zręcznie i tak samo bezmyślnie, jak robią wszystko inne. [...] Poddane temu procesowi działania kiedyś stanowiły cel sam w sobie, teraz są już tylko środkami do celu (Deresiewicz 2014).

Proces niekończącej się walki o pozycję wywiera znaczną presję na szkoły wyższe. Ich prestiż (wyznaczany ogólnokrajowymi i międzynarodowymi rankingami uniwersytetów) wiąże się z osiągnięciami naukowymi profesorów i selektywnością procesu rekrutacji. Odpad szkolny wpływa negatywnie na pozycję w rankingach. Kiedy więc szkoły przyjmą już „najlepszych z najlepszych”, tracą jakąkolwiek motywację do prowadzenia dalszego odsiewu. Wyrzucanie studentów nie jest ani w interesie zajętych prawie wyłączenie badaniami wykładowców, ani karanych za nie w rankingach szkół, ani - co oczywiste - samych uczniów i ich rodziców. $\mathrm{W}$ rezultacie

Pomiędzy profesorami i studentami zapanował, słowami jednego z obserwatorów, „pakt o wzajemnej nieagresji". Studenci chcą robić tak mało jak to możliwe. Nagradzani za badania profesorowie, szczególnie w elitarnych szkołach, pragną spędzać jak najmniej czasu na katedrze (Deresiewicz 2014).

W konsekwencji szkolące merytokratyczną elitę instytucje zrezygnowały z funkcji wychowawczej, a także - w dużym stopniu - edukacyjnej. Dostanie się do nich jest niezwykle trudne, ale o ile

Próg jest wysoki, a pokonanie go niełatwe, [to] gdy jesteś już w środku, nie ma prawie nic, co mógłbyś zrobić, by cię wyrzucono. Najgorsze akademickie porażki, najbardziej bezczelne plagiaty, a nawet grożenie przemocą innym studentom [...] nie są wystarczającym powodem dla wydalenia ze szkoły. Gdy już raz znajdziesz się w klubie [...] masz święte prawo pozostać w nim na zawsze. [...] Innymi słowy, dzieciom w prestiżowych szkołach zapewnia się nieograniczoną ilość drugich szans (Deresiewicz 2014).

Niezwykła łagodność, z jaką traktowani są studenci elitarnych uniwersytetów, nie rozciąga się na uczniów pośledniejszych szkół. Po pierwsze instytucje te i tak nie mają szans na osiągnięcie wysokich pozycji w rankingach (a drastyczny odsiew podobnie jak na polskich uniwersytetach - może wiązać się z przewagami natury finansowej), pod drugie ich studentów czeka zupełnie inny los niż absolwentów selektywnych koledży:

Ludzi tych [...] trenuje się do zajmowania pozycji w samym środku system klasowego, w czeluściach tej czy innej biurokracji. Przygotowuje się do życia bez drugich szans i przedłużonych terminów, życia pozbawionego okazji do rozwoju i jakiegokolwiek wsparcia, spędzanego w warunkach podporządkowania, nadzoru i kontroli (Deresiewicz 2014). 
Te różnice - pomiędzy elitami, którym wybacza się wszystko, i poddaną drobiazgowemu nadzorowi klasą średnią - nie zamierają, gdy obie grupy przekraczają progi swoich uczelni. Ulegitymizowane przez edukację nierówności strukturyzują całe życie społeczne - pozbawiona "talentu” klasa średnia funkcjonuje w coraz ściślejszym gorsecie regulacji, a „najlepsi” unikają odpowiedzialności, nawet gdy ich działania prowadzą gospodarkę na skraj upadku. Ta drastyczna nierównowaga nie wywołuje reakcji ze strony wywodzących się z elit polityków, ponieważ nie jest uznawana za problem społeczny, tylko część tego, co w merytokracji rozumie się pod pojęciem „sprawiedliwości”.

\section{Pedagogika elit i pedagogika mas}

Absolwenci najlepszych szkół różnią się od większości elit pieniądza czy urodzenia tym, że nie tylko uzyskali instytucjonalną gwarancję własnej przewagi, ale też, że sposób, w jaki ją zdobyli - biorąc udział w bezlitosnej konkurencji o niewielką liczbę miejsc w selektywnych koledżach - pozwala im wierzyć, że wszystko, co mają, zawdzięczają własnej pracy i umiejętnościom. Akceptacja dla własnej pozycji wymaga od nich uznania istniejącego stanu rzeczy za fundamentalnie sprawiedliwy. Jak pisze Thomas Frank,

Nie czują żadnej sympatii dla swoich, mających mniej szczęścia rówieśników - adiunktów odciętych od profesury, kolegów zwolnionych z pracy czy dzieci, które nie dostały się do „dobrych" koledży. To, że życie nie nagradza tych, którzy nie byli zdolni stanąć na wysokości zadania, nie jest czymś gorszącym czy przejawem niesprawiedliwości. Oznacza to, że rzeczy mają się dokładnie tak, jak mieć się powinny. [...] Solidarność [...] jest sprzeczna z doktryną osobistej doskonałości (Frank 2016b).

Zgoda na nierówności wyniesiona zarówno z poświęconych walce o pozycję domów, jak i z opartego na konkurencji systemu edukacyjnego jest rozciągana na cały system społeczny. Paradoksalnie jest to największa słabość systemu merytokratycznego i przyczyna jego postępującej degeneracji. Uniemożliwiła ona politycznej reprezentacji merytokratycznych elit USA - którą (ze względu na jej poparcie dla zasady równości szans) została centrolewicowa Partia Demokratyczna, a nie centroprawicowi (i obsługujący interesy raczej arystokracji finansowej niż kulturowej) Republikanie - walkę z rosnącymi od lat osiemdziesiątych nierównościami. Zaostrzenie nierówności (będące - według Franka - bezpośrednią konsekwencją doktryny mówiącej, że zdolnym należy się wszystko, a tym pozbawionym zdolności - bardzo niewiele) ma dwie konsekwencje. Po pierwsze stawka w walce o pozycję jest coraz wyższa, ponieważ rozziew pomiędzy (coraz lepiej nagradzanym) sukcesem a (coraz silniej karaną) porażką stale rośnie. W konsekwencji rośnie również motywacja kulturowej arystokracji do inwestowania w przyszłość jej dzieci - po to, by nie doświadczyły one bezwzględnych konsekwencji edukacyjnego niepowodzenia. Po drugie, ponieważ kapitał kulturowy, w bardziej bezpośredni sposób niż wcześniej, przekłada się na status finansowy, więc (silnie 
zmotywowani) rodzice z wyższej klasy średniej posiadają nad resztą społeczeństwa podwójną (kulturową i finansową) przewagę. Jeśli dodać do tego przewagę w zakresie kapitału społecznego, jaką uzyskali podczas własnych studiów, staje się jasne, że nie ma grupy społecznej (z wyjątkiem najbogatszych, tych jest jednak niewielu), która mogłaby konkurować z dziećmi merytokratycznej elity o miejsca w prestiżowych szkołach.

Jest to o tyle paradoksalne, że - zgodnie z liberalnym credo - to właśnie edukacja (a nie na przykład redystrybucja dochodów) ma stanowić rozwiązanie wszystkich społecznych problemów - z nierównościami włącznie:

Koledże pozwolą pokonać bezrobocie, a także rasizm, upadek miast i nierówności. Edukacja uczyni nas bardziej tolerancyjnymi, usunie nasze wątpliwości co do globalizacji i zmian klimatu, da nam umiejętności konieczne, by zachować konkurencyjność wobec innych społeczeństw. [...] Nie ma społecznego czy politycznego problemu, którego nie dałoby się rozwiązać za pomocą większej ilości edukacji czy szkoleń zawodowych. Jedyną krytyką, jaką można skierować wobec ukochanych instytucji jest ta mówiąca, że i one nie są dostatecznie merytokratyczne (Frank 2016b).

Paradoks tej sytuacji polega na tym, że przedstawiając (i politycznie promując) wykształcenie jako receptę na wszystkie problemy, merytokraci odcinają jednocześnie reszcie społeczeństwa dostęp do jedynych instytucji, które mogą zapewnić godne życie w nierównym społeczeństwie. Odcinają go, zapełniając je szczelnie własnymi dziećmi.

Liczby są jednoznaczne. W 1985 roku 46\% studentów 250 najbardziej selektywnych koledży pochodziło z górnego kwartyla rozkładu dochodów. W roku 2000 było ich już $55 \%$. W roku 2006 (dane te pochodzą z nieco mniejszej próby) $67 \%$. Tylko $15 \%$ studentów pochodziło w tym roku z biedniejszej połowy społeczeństwa. Nieco starsze badania oceniają liczbę osób z dolnego kwartyla dochodu na 3\% (Deresiewicz 2014).

Autor Twilight of the Elites Christopher Hayes nazywa ten proces (w nawiązaniu do słynnego sformułowania Roberta Michelsa) „żelaznym prawem merytokracji”:

Mówi [ono], że z czasem nierówności wytworzone przez merytokrację wzrosną w takim stopniu, że zatrzymają jakąkolwiek ruchliwość społeczną. Nierówność wyników czynią równość szans nieosiągalną. [...] Ci, którzy są zdolni do wspięcia się na drabinę, znajdą sposób, by zwinąć ją za sobą, lub opuszczać ją selektywnie tak, by dać szanse swoim przyjaciołom, sprzymierzeńcom i rodzinie. Innymi słowy: ktokolwiek mówi „merytokracja", zgadza się na oligarchię (Hayes 2012).

\section{Kto pilnuje strażników?}

Sprzeczność pomiędzy merytokracją i demokracją jest dla wszystkich przywoływanych tu autorów tak samo jasna jak sprzeczność pomiędzy demokracją a oligarchią. Wnioski te można by nieco złagodzić, gdyby „rządy najzdolniejszych” rzeczywiście były bardziej gospodarczo efektywne i bardziej sprzyjające społecznej 
spójności i tolerancji niż ich (często nie mniej hierarchiczne) alternatywy. Czy jest tak rzeczywiście? Odpowiedź zawarta w każdej z przywoływanych tu publikacji, jakkolwiek różni się stopniem radykalizmu, jest zgodna co do jednego - okres władzy merytokratycznej elity (pomijając kwestię zrównania szans edukacyjnych, której rezultaty są odczuwalne głównie w przypadku nierówności między płciami) - należy ocenić negatywnie.

Przyczyny tego stanu są złożone i dyskusja nad nimi wykracza poza zakres tej recenzji. Należałoby jednak zwrócić uwagę na trzy kwestie. Pierwszą z nich jest przedstawiana w poprzedniej sekcji zgoda na nierówności. Merytokraci widzą receptę na nią w edukacji. Nie są jednak zdolni dzielić się dostępem do tej ostatniej z innymi klasami społecznymi. Czyni to ze stałej pracy nad „poszerzaniem szans edukacyjnych" polityczną farsę.

Drugą jest kwestia fundamentalnego braku odpowiedzialności wynikającego zarówno z zasady nagradzania najlepszych, jak i faktu, że większość zawodów wykonywanych przez klasę wykształconą ma strukturę samorządnych profesji:

Choć jesteśmy przedmiotami ich diagnoz i recept, grupą, przed którą profesjonaliści czują się odpowiedzialni, nie jest opinia publiczna, ale właśni koledzy (i, oczywiście, klienci). [...] Profesyjna autonomia chroni ich przed koniecznością zwracania uwagi na głosy dobiegające spoza eksperckiego kręgu (Frank 2016b).

Bliskie związki władz państwowych z (często pochodzącymi z tych samych uniwersytetów) ekspertami, ze zdominowanym przez absolwentów szkół z Ligi Bluszczowej światem sądownictwa, adwokatury, biznesu i instytucji finansowych mogą poszerzać krąg osób, wobec których kulturowa arystokracja czuje się odpowiedzialna. To poszerzenie dotyczy jednak wyłącznie należących do innych kręgów i środowisk przedstawicieli tej samej elity. Dodatkowo hermetyczność środowisk władzy (występująca też w innych krajach, w których istnieją elitarne sektory edukacji wyższej), skutkuje powstaniem trzeciej przeszkody dla dobrych rządów - brakiem intelektualnej elastyczności, skłonności do podejmowania ryzyka i sprzeciwiania się ortodoksji. Źródła tego stanu rzeczy można odnaleźć już w bezlitosnym systemie selekcji, przez który musiał przedostać się każdy z członków kulturowej elity:

Standardy rekrutacji stały się tak ekstremalne, konkurencja tak brutalna, że dzieci, które dostają się do elitarnych koledży, z definicji nie doświadczyły niczego poza sukcesem. Możliwość porażki przeraża ich i dezorientuje [...]. Koszt niepowodzenia, nawet tymczasowego, nie jest kwestią praktyczną, tylko egzystencjalną. Konsekwencją tego jest gwałtowna awersja do podejmowania ryzyka. Jeśli nie masz marginesu błędu, starasz się unikać sytuacji, w których mógłbyś błąd popełnić. Jest to jedna z przyczyn, dla których elitarna edukacja stała się tak nieprzychylna procesowi nauczania. [...] Nikt nie chce ryzykować, wybierając przedmiot, w którym nie jest najlepszy, więc nikt nigdy nie podejmuje się zadań [...] w których wcześniej nie odnosił sukcesów (Deresiewicz 2014).

Konsekwencje polityczne tej zmiany w sposobie myślenia elit (stanowiące główny temat książki Franka i znaczą część materiału opisywanego przez Hayesa) wykraczają poza hermetyczność, związany z nią brak publicznej odpowiedzialności 
i intelektualnej otwartości czy brak skłonności do podejmowania ryzyka. To te cechy jednak odpowiadały za ostateczną porażkę rządów - będących według Hayesa „szczytowym osiągnięciem" merytokracji - Baraka Obamy w walce z problemami pozostawionymi przez jego poprzedników. Zaostrzenie nierówności i tym samym zwiększenie stawek działalności elit, czyhających na nie pokus i motywacji do uniknięcia przegranej w połączeniu z indywidualizmem - postrzeganiem własnej pozycji wyłącznie jako osobistej zasługi - prowadzi do powolnego rozkładu tkanki społecznej. Osoby spoza elity stają się ofiarami „nieuczciwych bankierów, nieuczciwych nauczycieli, a nawet nieuczciwych lekarzy" (Frank 2016b). Profesjonalna etyka jest zastępowana dążeniem do maksymalizacji zysków, a reputacja traci jakiekolwiek znaczenie:

Jest bardzo trudno zaprojektować oparty na konkurencji system, który rozdziela wysokie nagrody za osiągnięcia i jednocześnie nie nagradza oszustw. [...] Konsekwencją [...] jest postawienie reputacji na głowie. Ci, którzy angażują się w dające największe zyski oszustwa, organizujący pieniądze z najbardziej podejrzanych źródeł są powszechnie szanowani a na tych, którzy stawiają opór, lub jeszcze gorzej - chcą informować opinię publiczną - patrzy się podejrzliwie czy wręcz z pogardą (Hayes 2012).

Jednocześnie - podobnie jak w wypadku elitarnych szkół - żadne z patologicznych zachowań elit nie spotyka się z karą, co nie pozostaje bez wpływu na społeczną legitymizację istniejącego systemu rządów.

Te patologie można uznać za przejaw społecznych nierówności, a nie merytokracji jako takiej, jednak to ta ostatnia pozwoliła i nadal pozwala legitymizować je przed społeczeństwem. Co więcej, sam rdzeń merytokratycznego systemu w coraz większym stopniu opiera się na oszustwie. Szkoły, które mają dokonywać selekcji najzdolniejszych, w rzeczywistości wybierają swoich uczniów prawie wyłącznie z wąskiej grupy zamożnej wyższej klasy średniej. Kooptacja spoza społecznych elit, włączając w to programy pozytywnej dyskryminacji, pełni rolę listka figowego dla oliwionej pieniędzmi i kapitałem społecznym reprodukcji. „Zadaniem (bardzo niewielu) biednych, jacy dostają się na Harward, jest przekonanie (bardzo wielu) bogatych, że nie można po prostu kupić sobie miejsca w Harwardzie" (Deresiewicz 2014). Merytokracja obiecuje dobór "najlepszych”, ale nie jest w stanie tej obietnicy spełnić, a związane z nią koszty społeczne - dla społecznych dołów stawianych przed kolejnymi „bezalternatywnymi” reformami odbierającymi im środki do życia, dla klasy średniej dążącej do awansu społecznego, chociaż nie posiada ani pieniędzy, ani znajomości koniecznych, by wysłać swoje dzieci do najlepszych uniwersytetów, wreszcie dla elit od najmłodszych lat tresowanych do pożerającego całe dzieciństwo wyścigu szczurów - wydają się znacznie przekraczać możliwe zyski.

\section{Podsumowanie}

Edukacja elitarna na poziomie akademickim jest w Polsce fetyszyzowana w mniejszym stopniu niż w Stanach Zjednoczonych, ponieważ brakuje instytucji, 
które by ją oferowały. Sytuacja ta może jednak ulec zmianie. Proces reformowania systemu szkolnictwa wyższego i nauki trwa nadal, a jednym z jego celów - niezależnie od przynależności partyjnej kolejnych ministrów - jest zwiększenie selektywności najlepszych szkół, ograniczenie liczby wydawanych dyplomów magisterskich i hierarchizacja szkolnictwa wyższego. Plany te cieszą się powszechnym poparciem w środowisku akademickim tęskniącym do (całkiem niedawnych) czasów, gdy polski uniwersytet był instytucją przeznaczoną dla elit.

Książki, które przedstawiłem w ramach tej recenzji, powstały jako reakcja na patologie systemu, do którego powstania dążymy w Polsce od kilku lat. Amerykanie fetyszyzują swoje uniwersytety, a właściwie proces naboru do nich, w stopniu nieposiadającym historycznego precedensu. Nie należy jednak zakładać, że istnienie merytokratycznej elity miałoby odmienne konsekwencje nad Wisłą niż ma nad Potomakiem. Chociaż pojawienie się znacznych patologii gospodarczych wymaga istnienia silnie liberalnego systemu gospodarczego, patologie natury politycznej i społecznej przyjmują zbliżoną formę we wszystkich krajach, szkolących swoje elity w selektywnych szkołach. Zarówno Francja, jak i Wielka Brytania może się pochwalić klasą rządzącą podobnie hermetyczną, tak samo skorumpowaną i tak samo odizolowaną od nurtu codziennego życia jak Stany Zjednoczone. Wszystkie trzy kraje wyróżniają się też niezwykłą siłą populistycznej - czy może należałoby powiedzieć demokratycznej - reakcji na alienację elit.

Książki Hayesa, Deresiewicza i Franka - przy całej swojej niedoskonałości, wynikającej z publicystycznego i polemicznego, pozbawionego naukowego rygoru ujęcia problemu - mogą nam zaoferować wgląd w to, jak może wyglądać Polska, jeśli zapragniemy szkolić nasze własne merytokratyczne elity. Wbrew temu, co można czasem usłyszeć w sferze publicznej czy w akademickich dyskusjach, istnieje wiele alternatyw dla opisanego w nich systemu. Pozostaje mieć nadzieję, że będziemy mieli dość rozsądku, by wybrać jedną z nich.

\section{Literatura:}

Deresiewicz W., 2014, Excellent Sheep: The Miseducation of the American Elite and the Way to a Meaningful Life, New York: Free Press [Amazon Kindle Edition] [nlb.].

Frank T., 2016a, Millions of Ordinary Americans Support Donald Trump. Here's Why, https://www. theguardian.com/commentisfree/2016/mar/07/donald-trump-why-americans-support [dostęp: 22.11.2016].

Frank T., 2016b, Listen, Liberal: Or, What Ever Happened to the Party of the People, New York: Metropolitan Books [Amazon Kindle Edition] [nlb.].

Hayes C., 2012, Twilight of the Elites: America after Meritocracy, New York: Crown Publishers [Amazon Kindle Edition] [nlb.].

Karabel J., 2005, The Chosen: The Hidden History of Admission and Exclusion at Harvard, Yale and Princeton, Boston: Houghton Mifflin.

Melosik Z., 2015, Edukacja i stratyfikacja społeczna [w:] Nierówności społeczne. W trosce o otwarcia horyzontów edukacji, red. K. Błasińska et al., Gdańsk-Gdynia: Fundacja Instytut Równowagi Społeczno-Ekonomicznej-Wydawnictwo Region. 
Reuters, 2016, Obama: Hillary is most qualified presidential candidate in history, http://nypost. com/2016/07/05/obama-hillary-is-most-qualified-presidential-candidate-in-history/ [dostęp: 22.11.2016].

Shafer J., 2015, Donald Trump Talks Like a Thrid-Grader, http://www.politico.com/magazine/ story/2015/08/donald-trump-talks-like-a-third-grader-121340 [dostęp: 22.11.2016].

Stańczyk P., 2013, Człowiek, wychowanie i praca w kapitalizmie. W stronę krytycznej pedagogiki pracy, Gdańsk: Wydawnictwo Uniwersytetu Gdańskiego.

Starego K., 2016, Odmowa teraźniejszości, czyli o odobywatelnianiu dzieci i udziecinnianiu obywateli, „Teraźniejszość - Człowiek - Edukacja” nr 3. 